\title{
Impact Analysis of the 2020 PSBB Policy Enforcement on Online Taxi Driver's Income During the Covid-19 Pandemic in DKI Jakarta
}

\author{
Dwi Fazriani Ashal ${ }^{1}$, Dewi Khairani ${ }^{2}$, Yusuf Durachman ${ }^{3}$ \\ \{dwi.fazriani17@mhs.uinjkt.ac.id ${ }^{1}$, dewi.khairani@uinjkt.ac.id², yusuf_durachman@uinjkt.ac.id ${ }^{3}$ \}
}

UIN Syarif Hidayatullah Jakarta ${ }^{123}$

\begin{abstract}
Public transportation is a means of transportation that is needed in several developing countries. One of the means of ground transportation is a taxi. Transportation plays an important role in meeting diverse human needs, such as the need for education, health, economy and others. Along with technological advances and the important role of transportation in everyday life, online-based transportation has been created, both online motorcycle taxis and online taxis. This study aims to see the extent of the impact of the implementation of the PSBB policy on the income of taxi drivers during the Covid-19 pandemic. This study used a qualitative method approach and involved 8 direct informants, namely online taxi drivers. The results of this study as a whole show that the existence of the PSBB policy that is enforced in DKI Jakarta in particular has a large negative impact. This policy causes the income of taxi drivers to decrease even up to $80 \%$ and it makes it very difficult to continue their daily life. The government has 5 programs to help the community including (1) Family Hope Program (PKH) for 10 Million Beneficiary Families (KPM), (2) Basic Food Card Program for 20 million recipients, (3) Pre-Work Card Program for 5.6 million participants with a total budget of IDR 20 trillion, (4) The government provides discounted rates for 450 VA customers and 900 VA subsidies, (5) Stimulus of People's Business Credit (KUR) which aims to ease the burden on SME.
\end{abstract}

Keywords: Impact, Income, PSBB Policy, Covid-19 and Online Taxi.

\section{Introduction}

Transportation can be defined as an activity to move a person (person or goods) from one place to another separately. The existence of transportation is none other than supporting daily human activities, and is a means of human mobility on land, sea and air. With certain control and control systems (traffic management, operating systems, and device procedures). That was Jinca's explanation[1]. One of the means of land transportation is taxis, taxis are a means of land transportation that have grown and developed quite rapidly and are one of the prima donna modes of transportation in several big cities including Jakarta.

Transportation plays an important role in meeting diverse human needs, such as the need for education, health, economy and others. Along with technological advances and the important role of transportation in everyday life, online-based transportation has been created, both online motorcycle taxis and online taxis. Online-based taxis have appeared in Indonesia, especially in big cities such as; Jakarta, Surabaya, Jogjakarta, and Bandung since 2015. The 
emergence of online taxis in Indonesia has been greeted positively by the Indonesian people, because people consider that the presence of online taxis helps the needs of the community, helps people to travel to a place and can reduce unemployment in Indonesia. Some people who use online taxi services claim to be facilitated by the services provided by online taxi service providers in the form of on-site pick-up services. They only need to order online taxi services using their smartphones. We cannot hinder the development of the times. The more advanced this era is, the more sophisticated the technology is. What makes it interesting is the existence of this transportation which continues to operate in the midst of a virus outbreak that is currently sweeping all over the world, without exception, Indonesia. Coronavirus is a group of viruses that can cause disease in animals or humans. Several types of coronavirus are known to cause respiratory tract infections in humans ranging from cold coughs to more serious ones such as Middle East Respiratory Syndrome (MERS) and Severe Acute Respiratory Syndrome (SARS). The newly discovered coronavirus causes the disease COVID19[2]. COVID-19 is an infectious disease caused by a newly discovered type of coronavirus. The new virus and the disease it causes were not known before the outbreak in Wuhan, China, in December 2019. COVID-19 is now a pandemic occurring in many countries around the world. The number of COVID-19 cases in Indonesia itself is now at 132,816 confirmed covid19 [3], and this has further weakened the national and international economy. Various business sectors are experiencing weakness due to this virus.

With the implementation of the Large-Scale Social Restrictions (LSSR) policy[4], stakeholders or business people must temporarily close their shops to break the chain of spreading this coronavirus. With the enactment of this large-scale limitation model, it certainly reduces passengers, which results in reduced income from taxi drivers. The increase in the price of basic necessities has also made life more difficult for taxi drivers, whose income is decreasing from day to day[5]. Taxi drivers as one of the informal sector professions in the transportation service sector experience socio-economic problems, especially in meeting the needs of family life.

Based on the background of the problems described above, the authors are interested in examining how the impact of the Corona Virus on the income of online taxi drivers at the time of implementing the PSBB policy in South Jakarta. So the authors compiled this study with the title "Analysis of the Impact of the PSBB Policy Enforcement Online Taxi Driver Income During the Covid-19 Pandemic in DKI Jakarta ".

\section{Methods}

\subsection{Approach This research}

Uses a qualitative method approach. According to [6], qualitative research is research that intends to understand the phenomena experienced by research subjects (for example behavior, perceptions, actions, etc.), holistically and by means of descriptions in the form of words and language, in a context. special nature and by making use of various scientific methods. Qualitative research is used to examine the conditions of natural objects where the researcher is the key instrument. The data collection technique is done by triangulation (combined), data analysis is inductive and the results of qualitative research emphasize meaning rather than generalization. It is called a qualitative method because the data collected and the analysis are more qualitative in nature. 


\subsection{Research Focus}

Determining the focus of research is important in qualitative research because it limits research to selecting which data is relevant and which is not relevant [6]. In accordance with the formulation of the problem, the focus of this study is to see how the impact of the implementation of the PSBB policy on changes in the income of online taxi drivers.

\subsection{Research Informants}

One of the characteristics of qualitative research is not too concerned with the number or number of informants, but more concerned with content, relevance, sources that can provide information, whether about people, events, or other things. Therefore, according to Sugiyono, the informant retrieval technique that is suitable for use in qualitative research is the purposive technique or the technique of taking informants which is determined based on certain considerations[7].

The informants in this study were taken from online taxi drivers, especially online taxi drivers in the DKI Jakarta area, as many as 8 people with the following details:

1. Online Taxi Driver : 7

2. Online Taxi Driver (Stop) : 1

\subsection{Data Collection Techniques}

The main data sources in qualitative research are words and actions; the rest is additional data such as documents and others. According to Maleong, qualitative research uses qualitative methods, namely observation, interviews, or document review.

The data collection techniques used in this study are as follows:

1. Interview (Interview). This interview technique is used to obtain primary data. Interviews were conducted by conducting direct questions and answers with informants, using interview guidelines that had been prepared.

2. Observation. This observation technique is used to observe directly the events / phenomena under study, in order to complement the primary data from the interviews

\subsection{Data Analysis Techniques}

The analysis technique used is a qualitative analysis of the interaction model of Miles and Huberman in Sugiono. The data analysis process begins with data collection, followed by data reduction, the data display and ends. 


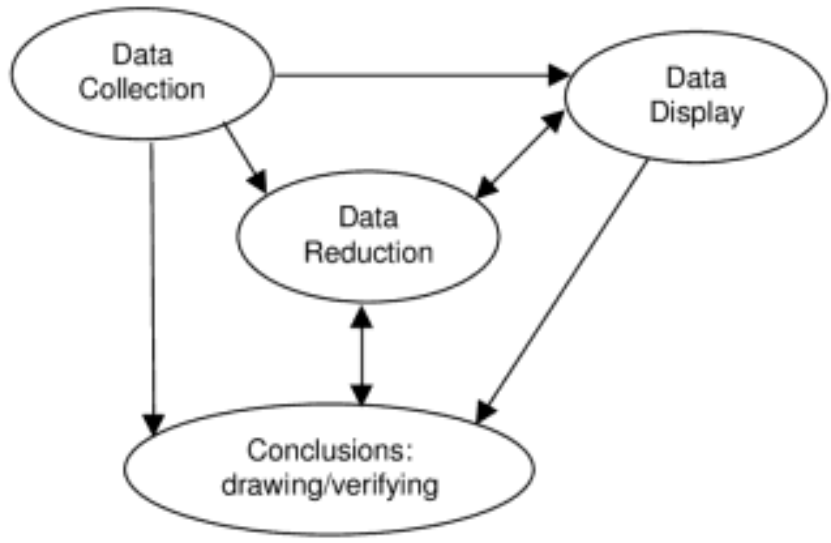

Fig. 1. Huberman, A.M \& M.B Miles (1984). Qualitative Data Analysis. Beverly Hills: Sage. 


\section{Literature Review}

Reminta Lumban Batu, et al., [8] in this research aims to investigate the effect of price and application service innovation on the decision to use Express Taxi services. The analysis shows that the price and application service innovation have a significant influence on service use decision variables. The results of this study enrich the literature on online taxi services. In addition, the results of this study are also useful for online taxi service managers to consider prices and service innovations in order to attract customer interest.

Arief Bowo Prayoga, at al., [9] in this research analyzed the Study of Brand Switching Behavior from Conventional Taxi Meters to Online Taxi. The sample of this study involved 155 respondents who used conventional taxi meters who had switched to online taxis in Jakarta. This study aims to determine what causes people's behavior in seeking variations in their needs in this technological era, especially on the causes of consumer movement from conventional taxis to online taxis. The results of this study indicate that product attributes affect brand switching decisions. Price setting affects brand switching decisions and variety seeking affects brand switching.

Yessa Fitri Yaning Tyas, et al., [10] in this research analyzes the characteristics of online taxi services to consumers. The sample in this study using normative law. This study aims to see the characteristics of online taxi services for consumers and also legal protection against consumers for the losses of online taxis. In this study, the results show that consumers have several complaints in the form of discomfort over the attitude of drivers who do not have ethics, both verbally and in deeds. This attitude will lead to potential harassment and other immoral acts.

Budi Setiawan, et al., [11] analyzed the Comparison of the Economic Impact of Network-Based Transportation and Conventional Transportation in Developing Countries: A Case Study in Palembang City. The sample in this study The population of the study were online taxi drivers and conventional taxi drivers in Palembang City. The research sample involved 20 online taxi drivers and 20 conventional taxi drivers. Testing data using the independent sample $t$ test. The results showed that there was no difference between the income received by online taxi drivers and conventional taxi drivers.

Mojang Al Mukaromah, et al., [12] that analyzed the impact of online transportation on the socio-economic conditions of conventional transportation in Kediri. The sample of this research is data sampling using purposive sampling method and accidental sampling. This study aims to determine and describe the impact of online transportation on the socioeconomic conditions of conventional transportation in Kediri. The results of research conducted starting in March 2019 show that the arrival of online transportation in the City of Kediri has an impact on the socio-economic conditions of conventional transportation, namely a decrease in the income of conventional transportation drivers caused by tariff problems, shifting of passenger interest.

Anggi Syahrul Romadi, et al., [13] on his research analyzes the effect of tariffs on the choice of online and conventional modes of transportation in the city of Banyuwangi. The purpose of this study was to determine the characteristics of travelers and the probability of travelers in choosing the mode of transportation. This study used stated preference methods, then processed it with a binomial logit model. The survey was conducted with the distribution to 100 respondents. On the difference in tariff (X1) the probability of online transportation is $75 \%$, the probability of conventional transportation is $25 \%$. The utility equation obtained is $\mathrm{Y}$ $=1.143+0.000 \times 1$. 


\section{Results and Discussion}

Large-scale social restrictions (LSSR) in DKI Jakarta[14], which began on April 10, 2020, have been effective. The enforcement of this rule also affects online transportation operations. With the enforcement of the PSBB regulations, all Grab and Go-Jek applications are not allowed to carry passengers[15]. In addition, the number of passengers for online taxi services is also limited. Based on the monitoring of various media sites, for the online motorcycle taxi service provided by Grab, namely Grabbike, when an order is made to go to Jakarta, the service will instead be diverted to Grabcar. And for the Grabcar service, the number of passengers is also limited, namely for vehicles such as sedans, the statement is only for 1-2 passengers, while for larger vehicles the number of passengers is only 1-3 passengers[16]. Four-wheeled transportation services are still allowed to operate with a maximum number of passengers of 2 people so that physical distancing can be maintained.

Chief of Corporate Affairs Gojek Indonesia[17], Nila Marita explained the prohibition of online motorcycle taxis or taxis carrying passengers during the implementation of the PSBB. All comply with the DKI Jakarta government's decision regarding the implementation of this PSBB as an effort to prevent and break the chain of spread of the coronavirus.

And for Go Food food delivery services, telematics services and GoMed drug delivery, as well as goods delivery services GoSend, GoMart, GoShop and GoBox continue to operate serving the public during the PSBB period. And the public or consumers can still use this service without direct physical contact. Online motorcycle taxi and taxi applicator partners consider that the implementation of the Large-Scale Social Restriction (LSSR) policy in DKI Jakarta is not quite right. This is because the regulations that have been in effect since Friday, April 102020 are not accompanied by a series of supporting policies, which can be a way out for informal workers such as taxis and online motorcycle taxis. Chairman of the Online Driver Association (ADO) Wiwit Sudarsono, both taxis and online motorcycle taxis are experiencing a decline in income of up to $80 \%$ after the enactment of the Work From Home (WFH) rule.

With the implementation of a policy that prohibits online motorcycle taxis or online taxis from transporting people, the government should provide a solution. Because with the demands given to drivers, the income of these drivers has decreased by up to $80 \%$ [18], especially those who are married and require to support their family, or pay installments. Here, direct subsidies are needed so that you can still get income to support your family and pay the installments for your vehicle.

This enforcement continues to be implemented and thus the driver's income or income remains stagnant in a decreasing range. Therefore, online driver partners who join various associations or organizations make a joint agreement letter to ask the government and applicators to reconsider matters related to welfare in the midst of the coronavirus pandemic (covid-19). There are three demands put forward[19], namely:

1. Requesting the government to provide Direct Cash Assistance (BLT) to business actors in the online transportation sector whose distribution is through business actors' organizations.

2. Requesting the government to provide clarity and certainty regarding the relaxation or suspension of vehicle installments to drivers of special rental transportation (ASK) until normal conditions.

3. Ask the applicant to postpone the $20 \%$ discount until the situation returns to normal and equip partners with personal protective equipment (PPE) in carrying out work and conduct campaigns to the community that special rental transportation is safe.

The Ministry of Transportation (Kemenhub) issued a circular letter to the Director General (Dirjen) regarding transportation operational instructions for the implementation of travel 
restrictions for people in order to accelerate the handling of COVID-19[20]. The issuance of the SE Director General is in order to follow up the issuance of the circular letter on Task Force for the Acceleration of Handling COVID-19 Number 4 of 2020.

In general, the SE Director General regulates the operational instructions for transportation in each mode, including land, sea, air and rail. The Elements stakeholder involved consist of the local government, the Task Force for the Acceleration of Handling Covid-19, and operators of transportation facilities and infrastructure.

The main duties of the Ministry of Transportation in the field, namely the Heads of Land Transportation Centers, Harbormaster, Head of Airport Authority Offices, and Head of Railway Engineering Centers, are tasked with:

1. Supervising and controlling the implementation of the Task Force which in its implementation coordinates with transportation operators, TNI, The National Police, the Regional Government, the Covid-19 Task Force and other related agencies.

2. Supervise and ensure the establishment of guard posts and inspection by transportation operators in every transportation infrastructure including terminals, stations, airports and ports in accordance with health protocols.

3. Ensure transportation operators carry out the provisions of the circular latter on Task Force.

4. Report the results of supervision to each Director General.

Meanwhile, from the operator and transportation infrastructure element, the task is to:

1. Implement and comply with the provisions in circular letter on Task Force

2. Ensure ticket bookings can only be made through the head office or branches of the transportation operator.

3. Must ensure that prospective passengers meet the criteria and requirements stipulated in the circular letter on Task Force before being given a ticket.

4. Must ensure that the crews / officers of the operators of transportation facilities and infrastructure and passengers comply with health protocols at the time of departure, on the way, and upon arrival at their destination.

As stated in the circular letter of the Task Force that control, supervision and law enforcement are carried out by a joint team of local governments and elements of the TNIPolri and transportation operators. If there are indications of violations, a sanction will be given in accordance with the applicable laws.

With the existence of a letter of agreement given to the government from every online driver association and organization, one of which contains asking the government to provide Direct Cash Assistance (BLT) to business actors in the online transportation sector whose distribution is through business actors' organizations. With the requests from various associations and actors, President Joko Widodo has come (Jokowi) decided to provide social protection assistance to informal workers such as taxi drivers, bus drivers, trucks to the kernet[21]. This assistance is still in the context of tackling the impact of the outbreak COVID-19.

Reporting from the finance.detik.com site, the government, namely President Joko Widodo, will provide assistance. The assistance provided will later enter into the safety program implemented by the Indonesian Police. Jokowi said the safety program was almost the same as the Pre-Work Card program. However, this program combines social assistance (bansos) with training. With the issued target of 197 thousand taxi drivers, bus / truck and kernet drivers, an incentive of IDR 600 thousand per month will be given for 3 months. The budget prepared is IDR 360 billion. 
The government has also conveyed several social protection policies for people whose economies are affected by the Coronavirus (COVID-19)[22]. The first is the Family of Hope Program (PKH) for 10 Million Beneficiary Families (KPM). The distribution of PKH, which was previously per 3 months, will be made per month starting April. For April-June, KPM will receive PKH twice. The duration of this distribution will last for 1 year, with an increase in the budget from the previous Rp 29.13 trillion to Rp 37.4 trillion.

Second, the basic food card program for 20 million recipients. Previously, this program was for 15.2 million existing recipients with a total of IDR 150 thousand per month from January to February. Currently, there are an additional 4.8 million additional recipients with an amount of Rp 200 thousand per month from March to December. With this addition, the total budget prepared will be Rp 43.6 trillion from the previous Rp 28.08 trillion.

Third, the Pre-Work Card program for 5.6 million participants with a total budget of IDR 20 trillion. From this program, each participant will receive training fees, monthly incentives and surveys with a total amount of $\mathrm{Rp} 3.55$ million. Currently, the government is also collecting data on workers affected by COVID-19, both those who have been laid off, have been sent home with unpaid leave, or those who have experienced a decrease in income, who will then be prioritized as recipients of pre-work cards.

Fourth, the government provides discounted rates for $450 \mathrm{VA}$ customers and $900 \mathrm{VA}$ subsidies. From the data, 450 VA households are 24 million customers, and will be given an electricity fee exemption. Meanwhile, for subsidized 900 VA households, 7 million customers will be given a $50 \%$ reduction in electricity costs. The validity period of this waiver is AprilJune 2020.

Fifth, the stimulus for the People's Business Credit (KUR) which aims to ease the burden on MSMEs. The policy scheme is through relaxation of the KUR distribution policy, through postponement of installments and an exemption of interest for 6 months.

With the assistance provided by the government, it hopes to help informal business actors affected by the corona virus or Covid-19. Through programs that have been issued by the government, later on, they will still provide a source of food or life for people who feel affected by this virus and can continue their daily activities even in limited conditions with regulations that require all people to social \& physical distancing.

The results of this study as a whole show that the existence of the PSBB policy that is enforced in DKI Jakarta in particular has a large negative impact. This policy causes the driver's or taxi driver's income to decrease even up to $80 \%$ and it makes it very difficult for them to continue their daily life.

With the large negative impact of the implementation of the PSBB policy due to the coronavirus, this implies the need for the government to better regulate and focus more on these informal workers by paying attention to the interests of all parties, both entrepreneurs or drivers, the community and also for the increasingly successful national economy. It gets worse if we look at the data that continues to be issued by the Minister of Finance or from the World Bank.

\section{Conclusion}

5.1 Conclusion

The existence of transportation is nothing but a support for everyday human activities, and a means of human mobility on land, sea and air. With certain control and control systems (traffic management, operating systems, and device procedures). One of the means of land transportation is taxis, taxis are a means of land transportation that have grown 
and developed quite rapidly and are one of the prima donna modes of transportation in several big cities including Jakarta.

In 2020, the global economy cannot be measured only in the scope of the economy itself. The Coronavirus (Covid-19) is proof that a virus that disrupts health can cause economic instability in a country even on a global scale. With the large-scale social restrictions (LSSR) policy, stakeholders or business people must temporarily close their shops in order to break the chain of spreading this coronavirus. With the enactment of this largescale limitation model, it certainly reduces passengers, which results in reduced income from taxi drivers. The increase in the price of basic necessities has also made life more difficult for taxi drivers, whose income is decreasing from day to day. Taxi drivers as one of the informal sector professions in the transportation service sector experience socio-economic problems, especially in meeting the needs of family life.

The corona virus outbreak (COVID-19) has had a considerable impact on the Indonesian economy. The impact could be minimized, but it depends on the policies taken by the government to overcome it. With various discussions and elaborations that I have explained above, as well as with the programs that have been issued with several stimuli both fiscal and monetary. Including policies related to anticipating the impact of Covid-19 transmission on the domestic economy (Economic stimulus I, II and III). The programs that have been implemented by the government include:

1. Family of Hope Program (PKH) for 10 Million Beneficiary Families (KPM)

2. Basic Food Card Program for 20 Million recipients

3. Pre-Work Card Program for 5.6 million participants with total budget of IDR 20 trillion

4. The government provides discounted rates for 450 VA customers and 900 VA subsidies.

5. Stimulus of People's Business Credit (KUR) which aims to ease the burden on Small and Medium Enterprise (SME).

With the assistance provided by the government, it hopes to help informal business actors affected by the corona virus or Covid-19. Through programs that have been issued by the government, in the future, it will still provide a source of food or life for people who feel affected by this virus and can continue their daily activities even in limited conditions with rules that require all people to social \& physical distancing.

\subsection{Suggestions}

I can present such regarding the problems arising from the implementation of the PSBB in the midst of the Covid Pandemic on taxi drivers in the Jakarta area, which is the subject of this paper, of course there are still many shortcomings and advantages, due to limited knowledge. Therefore, I hope that readers will give constructive criticism and suggestions to the compilers for the perfection of this paper and writing papers for the next opportunities.

Acknowledgments. This paper was supported by PPM UIN Syarif Hidayatullah Jakarta for KKN-DR year 2020.

\section{References}

[1] MY. Jinca, "Dasar - Dasar Transportasi," Bahan Ajar Diklat Tek. Perhub. Tingkat Staf, Dep. Perhubungan. Makassar, p. 8, 2007.

[2] "Pertanyaan jawaban terkait COVID-19 untuk publik." [Online]. Available: https://www.who.int/indonesia/news/novel-coronavirus/qa-for-public. [Accessed: 14- Aug2020]. 
[3] "Berita Terkini | Gugus Tugas Percepatan Penanganan COVID-19." [Online]. Available: https://covid19.go.id/p/berita. [Accessed: 14-Aug-2020].

[4] "PSBB di Jakarta, 1.262 Perusahaan Tutup, 2.341 Lainnya Kurangi Kegiatan." [Online]. Available: https://megapolitan.kompas.com/read/2020/04/14/14534231/psbb-di-jakarta-1262perusahaan-tutup-2341-lainnya-kurangi-kegiatan. [Accessed: 14-Aug-2020].

[5] "Foto : Nasib Sopir Taksi di Tengah PSBB| merdeka.com." [Online]. Available: https://www.merdeka.com/foto/jakarta/1178738/20200519134423-nasib-sopir-taksi- $\quad$ ditengah-psbb-002-debby-restu-utomo.html. [Accessed: 14-Aug-2020].

[obi:[6] Lexy J. Maleong, Metodologi Penelitian Kualitatif. Bandung: Rajawali Pers, 2009.

[7] Sugiyono, Metode Penelitian Kuantitatif, Kualitatif dan R\&D. Bandung: Alfabeta,

2009.

[8] dan P. F. S. Reminta Lumban Batu, Nine Inten Suryani, Nita Septia, "Pengaruh Harga

dan Inovasi Layanan Aplikasi terhadap Keputusan Penggunaan Jasa Taksi Express: Survei pada Pengunduh Aplikasi Express Taxis," Manaj. SDM, PEMASARAN, DAN Keuang., vol. 01, 2020.

[9] Arief Bowo Prayoga Kasmo; Riska Jayanti, "Studi Brand Switching Behavior dari Taxi Meter Konvensional ke Taxi Online,” Inov. Bisnis dan Manaj. Indones., vol. 01, 2018.

[10] S. S. Tyas, Yessa Fitri Yaning, "Karakteristik Pelayanan Taxi Online Terhadap Konsumen," AKSARA PUBLIC, vol. 3, 2019.

[11] M. H. Budi Setiawan, "Perbandingan Dampak Ekonomi Transportasi Berbasis Jaringan dan Transportasi Konvensional di Negara Berkembang : Studi Kasus di Kota Palembang," Ilm. Ekon. Glob. Masa Kini, vol. 9, 2018.

[12] Mojang Al Mukaromah; Kartika Yuliari; Mohammad Arifin, "Dampak Keberadaan Transportasi On Line Terhadap Kondisi Sosial Ekonomi Transportasi Konvesional Di Kota Kediri," JIMEK, vol. 2, 2019.

[13] A. Siska Aprilia Hardiyanti, Wahyu Naris Wari, WNW, Anggi Syahrul Romadi, "Pengaruh Tarif terhadap Pemilihan Moda Transportasi Online dan Konvensional Di Kota Banyuwangi," Math. Comput. Sci., vol. 2, 2017.

[14] "Anies Resmi Terapkan PSBB di DKI Jakarta Jumat 10 April 2020.” [Online]. Available: https://www.cnnindonesia.com/nasional/20200407152446-20- 491265/anies-resmi-terapkanpsbb-di-dki-jakarta-jumat-10-april-2020. [Accessed: 14- Aug-2020].

[15] "Aturan Kemenkes \& Permenhub Soal Ojol di PSBB Bikin Bingung." [Online]. Available: $\quad$ https://www.cnbcindonesia.com/tech/20200413061513-37-151366/aturankemenkes-permenhub-soal-ojol-di-psbb-bikin-bingung. [Accessed: 14-Aug-2020].

[16] "GRABCAR-Peraturan Sosial Berskala Besar (PSBB) | Grab ID." [Online]. Available: https://www.grab.com/id/en/blog/driver/car/grabcar-peraturan-sosial-berskala-besar- $\quad$ psbb/. [Accessed: 14-Aug-2020].

[17] "Ojol Dilarang Bawa Penumpang Saat PSBB, Ini Tanggapan Gojek dan Grab

Halaman all - Kompas.com." [Online]. Available: https://www.kompas.com/tren/read/2020/04/07/193000265/ojol-dilarang-bawa- penumpangsaat-psbb-ini-tanggapan-gojek-dan-grab?page=all. [Accessed: 14-Aug- 2020].

[18] "Corona Bikin Order Sepi, Driver Taksi Online Surati Jokowi." [Online]. Available: https://oto.detik.com/berita/d-4951047/corona-bikin-order-sepi-driver-taksi-online- $\quad$ suratijokowi. [Accessed: 14-Aug-2020].

[19] "Poin Tuntutan Ojek dan Taksi 'Online' Terkait PSBB Jakarta." [Online]. Available: https://www.cnnindonesia.com/teknologi/20200408052945-384-491427/poin- tuntutan-ojekdan-taksi-online-terkait-psbb-jakarta. [Accessed: 14-Aug-2020]. 
[20] "KEMENHUB TELAH TERBITKAN SE DIRJEN TENTANG PETUNJUK OPERASIONAL TRANSPORTASI UNTUK TINDAKLANJUTI SE GUGUS

TUGAS." [Online]. Available: http://dephub.go.id/post/read/kemenhub-telah- terbitkan-sedirjen-tentang-petunjuk-operasional-transportasi-untuk-tindaklanjuti-se- gugus-tugas. [Accessed: 14-Aug-2020].

[21] “26.000 Sopir Terima Bantuan Rp1,8 Juta untuk 3 Bulan dari Polisi- RCTI+.”

[Online]. Available: https://www.rctiplus.com/trending/detail/162268/26.000-sopirterima-bantuan-rp1,8-juta-untuk-3-bulan-dari-polisi. [Accessed: 14-Aug-2020].

[22] "Catat! Ini Sederet Bansos Pemerintah Selama Darurat Corona." [Online]. Available: https:/finance.detik.com/berita-ekonomi-bisnis/d-4972353/catat-ini-sederet-bansospemerintah-selama-darurat-corona. [Accessed: 14-Aug-2020]. 